\title{
A METHOD FOR DETERMINING THE FOREST FIRE THREAT LEVEL
}

\author{
Mihailo RATKNIĆ ${ }^{l}$, Goran ĐORĐEVIĆ , Mileta BOJOVIĆ $^{3}$, Tatjana RATKNIĆ ${ }^{4}$
}

Summary: Articles 20, 22, 23, 24 and 27 of the Law on Fire Protection ('Official Gazette of RS', No 111/09) stipulate who and in what manner must prepare fire protection plans and what these plans must contain. The Regulation on classification of buildings, activities and land into a fire threat category ('Official Gazette of RS' No. 76/2010) prescribes a method of categorisation of fire protection subjects, stipulating that the legal entities classified into the first and the second fire threat category must prepare fire protection plans. A novelty in sub-legal regulation is the adoption of a special rulebook on preparation method and content of fire protection plans of autonomous provinces, local self-government units and subjects classified into the first and the second fire threat category ('Official Gazette of RS' No. 73/10). This sub-legal act prescribes the method and guidelines for preparation of fire protection plans, which is a substantial step forward in creation of a uniform procedure on preparation of fire protection plans. A serious shortcoming of this rulebook is that it only takes into account buildings, whereas the Law also stipulates categorisation of land and good-quality forested areas, as well as preparation of forest fire protection plans. Furthermore, the preparation of forest fire protection plans substantially differs from the preparation of fire protection plans for buildings. Creation of a planning act, such is a forest fire protection plan, entails development of methodologies that will provide the basis for the assessment of threat, or a fire occurrence risk, in a specific forest area.

\footnotetext{
${ }^{1}$ Mihailo Ratknić PhD, Institute of Forestry, Kneza Viseslava 3, Belgrade

${ }^{2}$ Goran Đorđević PhD, Emergency Sector, Požarevac Department

${ }^{3}$ Mileta Bojović, graduate engineer of geodesy, Energoprojekt - Hidroinžinjering, Mihaila Pupina 12, Belgrade

${ }^{4}$ Tatjana Ratknić MSc, Faculty of Applied Ecology 'Futura' Belgrade

Translation: Dejan Arsenovski
} 


\section{METODA ODREĐIVANJE STEPENA UGROŽENOSTI ŠUMA OD POŽARA}

Rezime: Zakonom o zaštiti od požara ('’Sl.glasnik RS'” br.111/09) svojim članovima 20,22,23,24 i 27 reguliše ko mora i na koji način da donese planove zaštite od požara i šta ti planovi moraju da sadrže. Uredbom o razvrstavanju objekata, delatnosti i zemljišta u kategoriju ugroženosti od požara ('’Sl.glasnik RS'" br.76/2010) daje se način kategorizacije subjekata zaštite od požara, prema kojoj pravni subjekti razvrstani i prvu $i$ drugu kategoriju ugroženosti od požara moraju da izrade plan zaštite od požara. Kao novina u podzakonskoj regulativi je donošenje posebnog pravilnika o načinu izrade $i$ sadržaju Planova zaštite od požara autonomnih pokrajina, jedinica lokalne samouprave $i$ subjekata razvrstanih u prvi i drugu kategoriju ugroženosti od požara ('Sl.glasnik RS'" br.73/10).Ovaj podzakonski akt daje način izrade planova zaštite od požara i smernice za izradu planova, što je suštinski pomak u jedinstvenom postupanju prilikom izrade planova zaštite od požara. Ono što je veliki nedostatak ovog pravilnika je to što on uzima u obzir samo građevinske objekte, dok Zakon definiše i kategorizaciju zemljišta i površina pod kvalitetnom šumom, i izradu planova zaštite šuma od požara koji se drastično razlikuju od izrade planova zaštite od požara za građevinske objekte. Da bi se izradio jedan planski akt kao što je plan zaštite šuma od požara, moraju se odrediti metodologije po kome će se određivati ugroženost, odnosno rizik od nastanka požara na određenom šumskom području.

\section{INTRODUCTION}

The Regulation on classification of buildings, activities and land into a fire threat category ('Official Gazette of RS' No. 76/2010) stipulates classification of land, that is, certain plan-covered areas, into the following fire threat categories:

- Category 1.7.: protected and high-quality forest areas with a surface area greater than 10,000 ha

- Category 1.8.: protected and high-quality forest areas with a surface area greater than $500-10,000$ ha

- Category 2.1.: protected and high-quality forest areas with a surface area greater than $800-5,000$ ha

- Category 2.2.: protected and high-quality forest areas with a surface area greater than 800 ha

The above-mentioned land categorisation entails preparation of forest fire protection plans not stipulated by the Rulebook on preparation of fire protection plans.

One of the key elements in preparation of fire protection plans is a fire threat assessment, the preparation of which requires development of a threat assessment methodology. Presently, a fire threat assessment in Serbia is performed in a manner in which only impact element taken into account is vegetation, without considering other elements that affect forest fire threat. However, this type of assessment method often does not provide a true picture of potential danger. Consequently, there was a need for preparation of a specific methodology for 
determination of forest fire threat, which would include all the elements that affect forest fire threat and be adjusted to domestic conditions of forest management.

A level of forest fire threat is not the same for all forests. It depends on a number of factors whose impact determines the individual level of threat. The statistics indicates that there is a continuous increase in number of forest fires and extent of burnt areas. The increase of forest fires correlates with numerous factors, the most important being the frequency and duration of drought periods, increased presence of people in forests, etc. A preventive and repressive action directly depends on a level of forest fire threat. Identifying this level enables timely and effective forest fire protection. The extent of burnt areas is directly related to the organisation and preparedness of subjects participating in forest fire prevention. Identifying a forest fire threat level entails anticipating potential dangers and determining forest fire prevention measures to be taken in a certain period. The main objective of this method, which may be subject to further enhancement, is to provide a technique and tactic for preparation of an effective forest fire prevention plan.

The increasing number of forest fires requires more organised and professional approach to forest fire protection. The risk of forest fire occurrence is defined as a probability function of adverse event occurrence and possible consequences. The probability of forest fires occurrence is always present; however, by taking certain preventive and organisational measures these adverse events can be anticipated and appropriate preventive measures can be taken. This can be achieved primarily by implementation of risk management in forest fire protection. Risk management involves a group of prevention measures and procedures, preparedness and responses to an occurred event, as well as remediation of adverse event effects with a view to reducing risk and creating conditions under which the risk level becomes tolerable. In risk management applied in forest fire prevention, preventive protection and a group of measures and activities aimed at preventing fire represent a particularly important segment in an effective forest fire protection. A forest fire threat assessment represents the first and primary segment in determining the initial risk of forest fire occurrence in a particular area. Professional services involved in forest fire protection must be well-acquainted with a forested area, particularly with all adverse changes taking place in that area; they must monitor those changes, record them in a timely manner and, based on the relevant parameters, take relevant prevention measures at the appropriate time.

\subsection{FOREST FIRE THREAT ASSESSMENT}

Forest fire as an ecological factor has a large impact on stability of ecological system. A number of forest fires and burnt areas are constantly increasing. It is associated with numerous factors, the most important being the frequency and duration of drought periods, climate changes, increased presence of people in forests, violation of legal regulations, etc. A large number of fires inflict a considerable damage, both material, relating to burnt wood mass, and ecological, social and other damage. If an excuse can be provided for an increased number of forest fires, the same cannot be the case with the scope of damage, as it is directly 
related to organisation and protection measures applied in forest fire protection. If forest fire protection measures are implemented timely, professionally, and in an organised manner, it can be expected that a number of burnt areas becomes lower, fire and dangers are timely foreseen and their number reduced, and the damage caused by forest fires is significantly decreased.

The main objective of a forest fire threat assessment is:

1. To present an accurate picture of a level of forest fire threat to the institutions involved in forest fire protection.

2. To determine and classify dangers arising from forest fires in a monitored area.

3. To point out to possibility of forest fire protection in a particular area and application of additional protection measures.

4. To point out to specificities and fire dangers in a monitored area to specialised agencies involved in fire protection and fire suppression.

5. To find models of additional protection measures and more effective fire suppression when a fire occurs in a particular area.

6. To present a methodology for performance of a fire threat assessment as the most important element in creation of planning acts such are forest fire protection plans, adjusted to the climate and characteristics of the area.

\section{Parameters used in a forest fire threat assessment}

Parameters that produce an impact on forest fire threat are numerous, but for the purpose of practical application of the threat assessment method, it will include only the parameters considered the most important and producing the strongest impact on forest fire threat. The key parameters used in forest fire threat assessment are:

a) vegetation and combustive material

b) natural phenomena producing an impact on fire occurrence

c) anthropogenic factor (human-induced risk)

d) climate characteristics

e) length of drought period

f) geological layer and pedological characteristics

g) orographic characteristics

h) openness of forest complex

i) a development level of an area for tourist and outing activities

j) other biotechnical protection measures

k) Fire record in the monitored area

\section{a) Vegetation and combustible material}

Vegetation, which consists of represented tree species and various types of combustible material in forest, represents the basis that is subject to direct or indirect impact of all other factors that create different levels of fire threat. 
Forests can be classified according to different criteria (types of trees, silvicultural method, age, function, etc); however, they are most commonly divided into: coniferous forests, deciduous forests and mixed forests. Furthermore, specific forms, such as thicket, scrub, maquis, garrigue, degraded forests are also taken into account due to their specificity in terms of fire sensibility. Under further vegetation classification, cultures in artificially established plantations are singled out as a specific category, regardless of their age, since the age does not affect a level of forest fire threat (in natural forests, as the age increases, the level of forest fire threat decreases), while in case of cultures, that difference is negligible.

A further division of natural coniferous, mixed and deciduous forests was conducted according to a forest's need for light and its age, although certain other properties of specific forest types also affect their fire threat level (content of resin, tannin, etheric oils, forest canopy, ground vegetation).

The main vegetation parameters used for determination of a forest fire threat level are presented in the Table 1

Table 1. Vegetation parameters used for determination of a forest fire threat level

\begin{tabular}{|l|c|}
\hline \multicolumn{1}{|c|}{ FOREST TYPE } & $\begin{array}{c}\text { Number of } \\
\text { points }\end{array}$ \\
\hline Category I & \\
\hline $\begin{array}{l}\text { Xerothermal and mesothermal coniferous forests (natural and artificial) type with a high resin } \\
\text { content }\end{array}$ & 200 \\
\hline Natural and artificially established black pine forests & 200 \\
\hline Natural and artificially established white pine forests & 200 \\
\hline Category II & 180 \\
\hline IIa- Xerothermal broadleaf forests & 180 \\
\hline Downy oak forests & 180 \\
\hline Flowering ash forests & 180 \\
\hline Oriental hornbeam forests & 180 \\
\hline Turkish oak forests & 180 \\
\hline IIb- Mesothermal broadleaf forests in warmer exposures & 180 \\
\hline Hop hornbeam forests & 180 \\
\hline Sessile oak forests & 180 \\
\hline Dalechampii oak forests & 160 \\
\hline Category III &
\end{tabular}

\begin{tabular}{|l|c|}
\hline Mesophilic and frigoriphilic forests (natural and artificial); type with a lower resin content & 160 \\
\hline Fir forests & 160 \\
\hline Spruce forests & 160 \\
\hline Serbian spruce forests & 160 \\
\hline Macedonian pine forests & 160 \\
\hline Artificially established larch stands & 160 \\
\hline Artificially established Douglas-fir stands & 160 \\
\hline Artificially established eastern white pine stands & 160 \\
\hline Artificially established abies grandis stands & 160 \\
\hline Artificially established stands of other species of the same characteristics & 160 \\
\hline Category IV & 140 \\
\hline IVa - Broadleaf and coniferous mesophilic and frigoriphilic mixed forests (natural and artificial) & 140 \\
\hline Fir forests & 140 \\
\hline Spruce forests & 140 \\
\hline Beech forests & 140 \\
\hline IVb - Mesophilic and mesothermal broadleaf mixed forests & 140 \\
\hline Common hornbeam and sessile oak forests & 140 \\
\hline Category V & 120 \\
\hline Forests dominated by mesophilic deciduous species & 120 \\
\hline
\end{tabular}




\begin{tabular}{|l|c|}
\hline Beech forests & 120 \\
\hline Common hornbeam forests & 120 \\
\hline Birch forests & 120 \\
\hline Aspen forests & 120 \\
\hline
\end{tabular}

\begin{tabular}{|l|c|}
\hline Stand condition based on a degradation level & $\begin{array}{c}\text { Number of } \\
\text { points }\end{array}$ \\
\hline Degraded stands & 100 \\
\hline Thickets & 160 \\
\hline Scrubs & 160 \\
\hline
\end{tabular}

\begin{tabular}{|l|c|}
\hline Stand age & $\begin{array}{c}\text { Number of } \\
\text { points }\end{array}$ \\
\hline Under 30 years of age & 80 \\
\hline 31 to 60 years of age & 60 \\
\hline Above 60 years of age & 40 \\
\hline
\end{tabular}

\begin{tabular}{|l|c|}
\hline Barren land condition & $\begin{array}{c}\text { Number of } \\
\text { points }\end{array}$ \\
\hline Category II & 180 \\
\hline Barren land in warmer exposures, thickly covered with ground vegetation & \\
\hline Category III & 140 \\
\hline Barren land on shady side, thickly covered with ground vegetation & \\
\hline Barren land on sunny side, sparsely covered with ground vegetation & 120 \\
\hline Category IV & \\
\hline $\begin{array}{l}\text { Barren land thickly covered with ground vegetation, dominated by } \\
\text { Saccinium myrtilis, Vaccinium vitis-ideus, Vaccinium uliginosum, Arictostaphillos uva-ursi and }\end{array}$ & \\
\hline Category V Barren land mainly without ground vegetation & 40 \\
\hline $\begin{array}{l}\text { Barren land in ground vegetation dominated by moss (particularly Sphagnum sp. and Hylocomium } \\
\text { sp.) or ferns Equisetum sp. }\end{array}$ & 20 \\
\hline Marshy smaller areas regardless of a coverage level and vegetation composition & 10 \\
\hline
\end{tabular}

\section{b) Natural phenomena that have an impact on forest fire occurrence}

Although natural phenomena that cause forest fires account for only $1 \%$ of the total fire causing agents in forests, this occurrence requires a particular attention. There are areas exposed to activity of certain natural phenomena, which can become frequent causing agents of forest fire occurrence in a particular period. The most common natural phenomena causing forest fires are atmospheric discharge and thunderbolt, along with the effect of sun heat, when the heat acquires certain focus and leads to ignition of combustive material, most frequently in form of dry grass. An increasing attention has been given to a theory that many forest fires occur by the agency of 'sun winds'; however, this theory has not been scientifically proved yet, therefore it will not be considered in the framework of this methodology. A natural phenomenon that occurs as a causing agent of a forest fire is atmospheric discharge.

Parameters identified on the basis of observation and the relation between danger and atmospheric discharge traces on trees are presented in Table 2. 
Table 2. Parameters used for determination of forest fire threat caused by atmospheric discharge

\begin{tabular}{|c|c|c|}
\hline $\begin{array}{c}\text { Number of atmospheric discharge } \\
\text { traces on trees } \\
\text { within a } 5 \mathrm{~km}^{2} \text { surface area }\end{array}$ & $\begin{array}{c}\text { Danger of tree and forest fire } \\
\text { occurrence }\end{array}$ & Number of points \\
\hline above 10 & considerable danger & 20 \\
\hline under 5 & danger exists & 10 \\
\hline under 2 & low danger & 0 \\
\hline
\end{tabular}

Atmospheric discharge is more common in higher than in lower mountain regions, as the tree height increases with an altitude. Discharges into high broadleaf trees are more frequent than discharges into coniferous trees.

\section{c) Anthropogenic factor - human-induced risk}

Nearly $98 \%$ of forest fires are directly or indirectly related to human activity. The presence of man in forests as a shepherd, tourist, forest fruit collector or hunter increases a specific forest fire threat. A particular threat arises from a man's activity related to fire ignition: burning of stubble or plant litter and use of fire in forests for any other type of purpose. Therefore, the anthropogenic threat occupies an important position among the forest fire threat factors.

Some of the indicators of anthropogenic impact on the forest fire threat level are presented in Table 3

Table 3. Parameters of anthropogenic impact on forest fire occurrence

\begin{tabular}{|l|c|}
\hline \multicolumn{1}{|c|}{ Category 1 } & Number of points \\
\hline $\begin{array}{l}\text { Tourist and recreation forests; forests in the vicinity of agricultural land and waste disposal } \\
\text { sites }\end{array}$ & 60 \\
\hline Category 2 & 40 \\
\hline Forests intersected by public roads, long-distance power lines or forests used as pasture & 20 \\
\hline Category 3 & \\
\hline $\begin{array}{l}\text { Forests in which forest fruit collection takes place, forests used for hunting and fishing and } \\
\text { forests in which silvicultural works are performed }\end{array}$ & 20 \\
\hline
\end{tabular}

If it is possible to classify forests into several categories according to a human-induced risk, than the impact of these factors on forest fire threat will be expressed by a total number of points.

\section{d) Climate and climate impact on forest fire threat}

Climate produces a joint effect with all other factors that have an impact on forest fire threat. Despite the fact that numerous climatic parameters have an impact on desiccation of combustible material (air temperature, relative air humidity, precipitations, wind, cloud cover, drought periods, etc.), only the tree most important parameters are used in a forest fire threat assessment: mean annual air temperature, mean annual amount of precipitation and mean annual relative humidity. When using these parameters, it is also necessary to include the duration 
of drought periods and their distribution in the course of a year into the assessment of climate impact on forest fire threat.

Some of the parameters used for assessment of climate impact on forest fire threat are presented in Table 4

Table 4. Parameters used for determination of the impact of climatic elements on

\begin{tabular}{|c|c|}
\hline Climate characteristics & $\begin{array}{c}\text { Number of } \\
\text { points }\end{array}$ \\
\hline \multicolumn{2}{|c|}{ Mean annual air temperature } \\
\hline above $12^{\circ} \mathrm{C}$ & 30 \\
\hline $9,1-12,0^{\circ} \mathrm{C}$ & 20 \\
\hline below $9,0^{\circ} \mathrm{C}$ & 10 \\
\hline \multicolumn{2}{|c|}{ Mean annual amount of precipitation } \\
\hline below $800 \mathrm{~mm}$ & 30 \\
\hline $801-1200 \mathrm{~mm}$ & 20 \\
\hline above $1200 \mathrm{~mm}$ & 10 \\
\hline \multicolumn{2}{|c|}{ Mean annual relative air humidity } \\
\hline below $70 \%$ & 30 \\
\hline $71-80 \%$ & 20 \\
\hline above $80 \%$ & 10 \\
\hline
\end{tabular}

\section{e) Drought period and its impact on forest threat}

A drought period and duration of drought period are also important in the assessment of level of forest fire threat. Duration of drought period, expressed by a number of days, is one of the most important elements used for determination of a level of forest fire threat. In order to identify the real danger and threat of forest fire, a classification into four three-month periods according to a corresponding level of danger, has been conducted, since the threat level is not the same in January or February, for instance, as it is July or August, when that danger is higher as a result of high air temperature. Furthermore, a number of dry days is also important for determination of a level of forest fire threat, since the length of duration of drought period is a relevant factor - it is natural that the danger is higher when a drought period is longer, particularly in months when the air temperature is extremely high - July, August and September, and when that danger is most serious.

Classification and division of drought periods based on months and number of days, along with a drought period impact on forest fire threat level expressed by points, are presented in Table 5 .

Table 5. Drought period parameters used for determination of a level of forest fire threat, [44]

\begin{tabular}{|l|c|}
\hline \multicolumn{1}{|c|}{ Number of dry days as per months } & $\begin{array}{c}\text { Number of } \\
\text { points }\end{array}$ \\
\hline FIRST PERIOD - January, February, March & \\
\hline under 10 days & 10 \\
\hline $10-20$ days & 20 \\
\hline more than 20 days & 30 \\
\hline SECOND PERIOD - April, May, June & 40 \\
\hline under 10 days & 40 \\
\hline
\end{tabular}




\begin{tabular}{|l|c|}
\hline $10-20$ days & 50 \\
\hline more than 20 days & 60 \\
\hline THIRD PERIOD - July, August, September & 70 \\
\hline under 10 days & 80 \\
\hline $10-20$ days & 90 \\
\hline more than 20 days & \\
\hline FOURTH PERIOD - October, November, December & 10 \\
\hline under 10 days & 20 \\
\hline $10-20$ days & 30 \\
\hline more than 20 days & \\
\hline
\end{tabular}

\section{f) A layer (parent substrate and soil type) and its impact on forest fire threat}

A layer, i.e., parent substrate and soil type, also has an impact on forest fire threat. The moisture content in combustible material (needles, leaves, twigs), along with a soil type, has an impact on condition and retention of water in ground and inner layers, which affects combustibility and the threat arising from combustible material in forests.

Classification of soil into categories and the corresponding fire threat level are presented in Table 6.

Table 6. Classification of soil and its impact on a level of forest fire threat

\begin{tabular}{|c|c|c|}
\hline Soil type & Subtype & $\begin{array}{l}\text { Number } \\
\text { of points }\end{array}$ \\
\hline A. Automorphic soils & & \\
\hline \multicolumn{3}{|c|}{ I - (A)-C or (A)-R undeveloped } \\
\hline \multirow{4}{*}{ Stone field (Lithosol) } & On acid rocks & 80 \\
\hline & On neutral and basic rocks & 80 \\
\hline & On peridotite & 80 \\
\hline & On limestone and dolomite & 80 \\
\hline \multirow{3}{*}{$\begin{array}{l}\text { Sierozem on loose substrate } \\
\text { (Regosol) }\end{array}$} & Siliceous & 80 \\
\hline & Siliceous-calcareous & 80 \\
\hline & Sand-dolomite & 80 \\
\hline \multirow{3}{*}{ Eolic 'quicksand' (Arenosol) } & Quartz & 80 \\
\hline & Siliceous & 80 \\
\hline & Siliceous- calcareous & 80 \\
\hline \multirow{3}{*}{ Colluvial soils (Colluvium) } & Distric-siliceous & 80 \\
\hline & Calcareous & 80 \\
\hline & With fossil soil & 80 \\
\hline
\end{tabular}

II - A-C or A-R (Humus-accumulative)

\begin{tabular}{|l|l|r|}
\hline \multicolumn{3}{|c|}{ II - A-C or A-R (Humus-accumulative) } \\
\hline Limestone - dolomite black soil (Calcomelanosol) & & 60 \\
\hline \multirow{4}{*}{ Rendzina } & On marl and marly and soft limestone & 80 \\
\cline { 2 - 3 } & On loess and loess-like sediments & 80 \\
\cline { 2 - 3 } & On moraine & 80 \\
\cline { 2 - 3 } & On dolomite regolith & 80 \\
\cline { 2 - 3 } & On calcareous sand & 80 \\
\cline { 2 - 3 } & On calcareous gravel & 80 \\
\hline \multirow{2}{*}{ Humus-siliceous (Ranker) } & Eutric & 80 \\
\cline { 2 - 3 } & Dystric & 60 \\
\hline \multirow{3}{*}{ Chernozem } & On loess and loess-like sediments & 80 \\
\cline { 2 - 3 } & On carobonate eolic sand & 80 \\
\cline { 2 - 3 } & On alluvial deposits & 60 \\
\hline \multirow{2}{*}{ Smonitza (Vertisol) } & Calcareous & 60 \\
\cline { 2 - 3 } & Non-calcareous & 60 \\
\cline { 2 - 3 } & Brownish & 60 \\
\hline
\end{tabular}




\begin{tabular}{|c|c|c|}
\hline \multicolumn{3}{|c|}{ III - A-(B)-C or A-(B)-R (Cambic) } \\
\hline \multirow{6}{*}{ Eutric brown (Eutric cambisol) } & On loess and loess-like sediments & 40 \\
\hline & On basic and neutral eruptive rocks & 40 \\
\hline & On peridotite and serpentinite & 40 \\
\hline & $\begin{array}{l}\text { On pond sediments } \\
\text { On alluvial, colluvial and eolic deposits }\end{array}$ & 40 \\
\hline & On claystone & 40 \\
\hline & On amphybolite shales & 40 \\
\hline \multirow{2}{*}{$\begin{array}{l}\text { Distric brown or acidic brown } \\
\text { (Distric cambisol) }\end{array}$} & Deep & 40 \\
\hline & Very deep & 20 \\
\hline \multirow{2}{*}{$\begin{array}{l}\text { Brown on limestone and dolomite } \\
\text { (Calcomelanosol) }\end{array}$} & Shallow and medium deep & 60 \\
\hline & Deep & 40 \\
\hline Red soil (Terra rossa) & & 60 \\
\hline \multicolumn{3}{|c|}{ IV - A-E-B-C or A-E-B-R (Fluvial illuvial) } \\
\hline \multirow{2}{*}{$\begin{array}{l}\text { Ilimerised or loess affected } \\
\text { (Luvisol) }\end{array}$} & On limestone & 40 \\
\hline & On siliceous rocks & 40 \\
\hline Podzol & & 40 \\
\hline \multirow{6}{*}{ Brown podzolic (Brunipodzol) } & On quartz sandstone & 20 \\
\hline & On quartz & 20 \\
\hline & On hornstone & 20 \\
\hline & On acidic eruptive rocks & 20 \\
\hline & On phyllite & 20 \\
\hline & On sand & 20 \\
\hline \multicolumn{3}{|c|}{ V-P-C (Anthropogenic) } \\
\hline \multicolumn{3}{|l|}{ Rigolano soil (Rigosol) } \\
\hline \multirow{2}{*}{\multicolumn{3}{|c|}{ Garden soil (Hortisol) }} \\
\hline & & \\
\hline \multicolumn{3}{|l|}{ Disposal site soil (Deposol) } \\
\hline \multicolumn{3}{|l|}{$\begin{array}{l}\text { Flotation material } \\
\text { (wastewater deposits - Flotisol) }\end{array}$} \\
\hline Air precipitates (Aeroprecipitate) & & \\
\hline
\end{tabular}

\begin{tabular}{|c|c|c|}
\hline B. Hydromorphic & & \\
\hline \multicolumn{3}{|c|}{$\mathrm{I}-\mathrm{A}-\mathrm{E} / \mathrm{g}-\mathrm{Bg}-\mathrm{C}-$ (Pseudogley) } \\
\hline Pseudogley & & 40 \\
\hline \multicolumn{3}{|c|}{ II - Layers or (A)-G ili (A) - C (Undeveloped) } \\
\hline \multirow{6}{*}{ Fluvial or alluvial (Fluvisol) } & Calcareous & 20 \\
\hline & Calcareous gleyed & 20 \\
\hline & Calcareous gleyed, saline and alkaline & 20 \\
\hline & Non-calcareous & 20 \\
\hline & Non-calcareous gleyed & 20 \\
\hline & Non-calcareous gleyed, saline and alkaline & 20 \\
\hline \multicolumn{3}{|c|}{ III - A-C-G - (Semi-gley) } \\
\hline Fluvial meadow (Humofluvisol) & & 20 \\
\hline \multicolumn{3}{|c|}{ IV - A-G-(Gley) } \\
\hline Pseudogley & & 40 \\
\hline Marsh black soil (Humogley) & & 20 \\
\hline Marsh gley (Eugley) & & 20 \\
\hline \multicolumn{3}{|c|}{$\mathrm{V}-\mathrm{T}-\mathrm{G}-($ Peat $)$} \\
\hline High peat & & 40 \\
\hline Combined high and low peat & & 20 \\
\hline Low peat (Planohistosol) & & 20 \\
\hline \multicolumn{3}{|c|}{ VI - P-G - (Anthropogenic) } \\
\hline Rigolano peat & & 0 \\
\hline Rice field soils & & 0 \\
\hline Hydromeliorated & & 0 \\
\hline
\end{tabular}




\begin{tabular}{|l|l|r|}
\hline C-Halomorphic soils & & \\
\hline & \multicolumn{2}{|l|}{} \\
\hline Solonchak I-Asa-G or Asa- CG - (Saline) & 40 \\
\hline & & \\
\hline Solonetz II - A/E-Asa-BT,na-C (Solonetzs) & 40 \\
\hline
\end{tabular}

\section{g) Orographic characteristics}

Among orographic characteristic, an altitude, inclination and terrain exposure have a pervasive impact. On terrains with a different altitude, exposure and inclination, the duration and intensity of sunrays are different and, consequently, so are the conditions for drying of combustive material (Table 7).

Table 7. Orographic parameters that have an impact on a level of forest fire threat

\begin{tabular}{|c|c|}
\hline Orographic characteristics & $\begin{array}{c}\text { Number of } \\
\text { points }\end{array}$ \\
\hline \multicolumn{2}{|l|}{ Exposure } \\
\hline South and level land & 20 \\
\hline East and West & 10 \\
\hline North & 5 \\
\hline \multicolumn{2}{|l|}{ Altitude } \\
\hline below $500 \mathrm{~m}$ & 15 \\
\hline $501-800 \mathrm{~m}$ & 10 \\
\hline above $800 \mathrm{~m}$ & 5 \\
\hline \multicolumn{2}{|l|}{ Inclination } \\
\hline above $45 \%$ & 15 \\
\hline $31-45 \%$ & 10 \\
\hline $15-30 \%$ & 5 \\
\hline
\end{tabular}

\section{h) Forest complex openness}

Openness of a forest complex for roads is the basis for a successful prevention of forest fire occurrence. That includes a proper maintenance of fire prevention clearance area, where twig removal and twig pruning are carried out, as well as thinning and reduction of combustible material.

\begin{tabular}{|l|c|}
\hline \multicolumn{1}{|c|}{ Forest complex openness } & $\begin{array}{c}\text { Number of } \\
\text { points }\end{array}$ \\
\hline $\begin{array}{l}\text { Forest complex is open (a large area of forest complex is accessible through a developed road } \\
\text { network, fire prevention rail tracks are regularly maintained) }\end{array}$ & 5 \\
\hline $\begin{array}{l}\text { Forest complex is partially open (larger areas of forest complex are poorly accessible, or } \\
\text { accessible by forest roads unsuitable for fire trucks; fire prevention rail tracks are poorly } \\
\text { maintained) }\end{array}$ & 20 \\
\hline Forest complex is not open, there are no fire prevention rail tracks & 40 \\
\hline
\end{tabular}

\section{i) the development level of an area for tourist and outing activities}

\begin{tabular}{|l|c|}
\hline \multicolumn{1}{|c|}{ Development level } & $\begin{array}{c}\text { Number of } \\
\text { points }\end{array}$ \\
\hline $\begin{array}{l}\text { Forest complex is well-developed for tourist and outing activities (areas designed for fire making } \\
\text { are properly marked and their safety is ensured, barrels with sand for extinguishing smaller fires }\end{array}$ & 5 \\
\hline
\end{tabular}


in the initial phase are provided, forest fire danger signs are properly placed)

Forest complex is partially developed for tourist and outing activities (forest fire danger signs are properly placed)

Forest complex is fully undeveloped for tourist and outing activities (there are no marked areas

for making fire nor forest fire danger signs)

\section{j) Other biotechnical protection measures}

\begin{tabular}{|l|c|}
\hline \multicolumn{1}{|c|}{ Development level } & $\begin{array}{c}\text { Number of } \\
\text { points }\end{array}$ \\
\hline $\begin{array}{l}\text { Forest complex has provided biotechnical protection measures (representation of mixed forests, } \\
\text { combustible material that is less susceptible to fire, construction of fire protection rail tracks, } \\
\text { condition and maintenance of water supply stations, construction of observation points and } \\
\text { organisation of forest monitoring system, creation and implementation of a fire occurrence } \\
\text { assessment system) }\end{array}$ & 5 \\
\hline Forest complex has no biotechnical protection measures & 40 \\
\hline
\end{tabular}

\section{k) Fire record and its impact on forest fire threat}

Fire record, or number of fires in a particular time interval in a specific area, has an impact on determination of the forest fire threat level. More specifically, the number of fire in a monitored area indicates what part of an area is more susceptible to fire occurrence and how increased a fire threat is. Furthermore, combustible material is not the same in areas with frequent fire occurrence, since the weather conditions that produce an impact on condition of combustible material susceptible to ignition, also change in that area. Some characteristics used for determination of a forest fire threat level, related to fire frequency in a monitored area within 10 years, are presented in Table 10.

Table 8. Fire record parameters that have an impact on a level of forest fire threat

\begin{tabular}{|l|c|}
\hline \multicolumn{1}{|c|}{ Number of fires in an area within a 10 year period } & $\begin{array}{c}\text { Number of } \\
\text { points }\end{array}$ \\
\hline 5 and above & 40 \\
\hline $2-4$ & 20 \\
\hline below 2 & 10 \\
\hline
\end{tabular}

\subsection{A level of forest fire threat}

Based on the above-mentioned parameters used for the assessment of forest fire threat, the points earned from the represented parameters are added; a level of forest fire threat is determined according to the total number of points.

Categorisation of forest fire threat based on the number of points is presented in Table 9.

Table 9. Forest fire threat categorisation

\begin{tabular}{|l|c|c|}
\hline \multicolumn{1}{|c|}{ Forest fire threat level } & Total number of points & Colour \\
\hline Level one - extremely high threat & $631-705$ & red \\
\hline Level two - high threat & $556-630$ & orange \\
\hline Level three - medium threat & $481-555$ & yellow \\
\hline Level four- low threat & $405-480$ & green \\
\hline
\end{tabular}


Based on certain numeric indicators of forest fire threat, fire threat maps are created in which areas exposed to fire threat are presented in relevant colours.

\section{CONCLUSION}

An increasingly frequent occurrence of forest fires and extensive burnt areas require a timely preventive forest fire protection. A type of forest fire threat assessment, which would include all elements that constitute and have an impact on forest fire threat, has not been conducted in Serbia by now, except for the threat assessment that is based on representation of tree species, while other parameters were not taken into consideration. A successful risk management in forest fire protection requires a first-hand knowledge and proper treatment of forests, particularly the understanding and observance of all adverse changes in forests, their timely recording and implementation of relevant fire prevention measures based on relevant parameters. Therefore, a timely detection of harmful occurrences requires a thorough knowledge of events that might cause forest fires, which is gained thorough a constant monitoring, data gathering and certain findings. A method for forest fire threat assessment has for its aim to determine, at any moment and based on a number of significant parameters, a level of forest fire threat in the observed area. Together with the system for forest fire threat assessment, the method for forest fire threat assessment provides the basis for an organised and professional approach to forest fire protection. A method for forest fire threat assessment must be the basis for any risk management applied in forest fire prevention. As any other, this method is also subject to changes and enhancement; however, in its present form, it provides a good basis for an appropriate assessment of forest fire threat. By means of application of this method, forest fire threat in any area can be determined in a more adequate manner. This type of method provides the basis for preparation of planning acts on classification of soils into categories according to forest fire threat. These plans fundamentally differ from the plans for building fire protection and therefore the current Rulebook on preparation of fire protection plans needs to be amended, primarily by defining the content and manner of preparation of these plans, as well as by defining a threat assessment method for preparation of forest fire protection plans. 


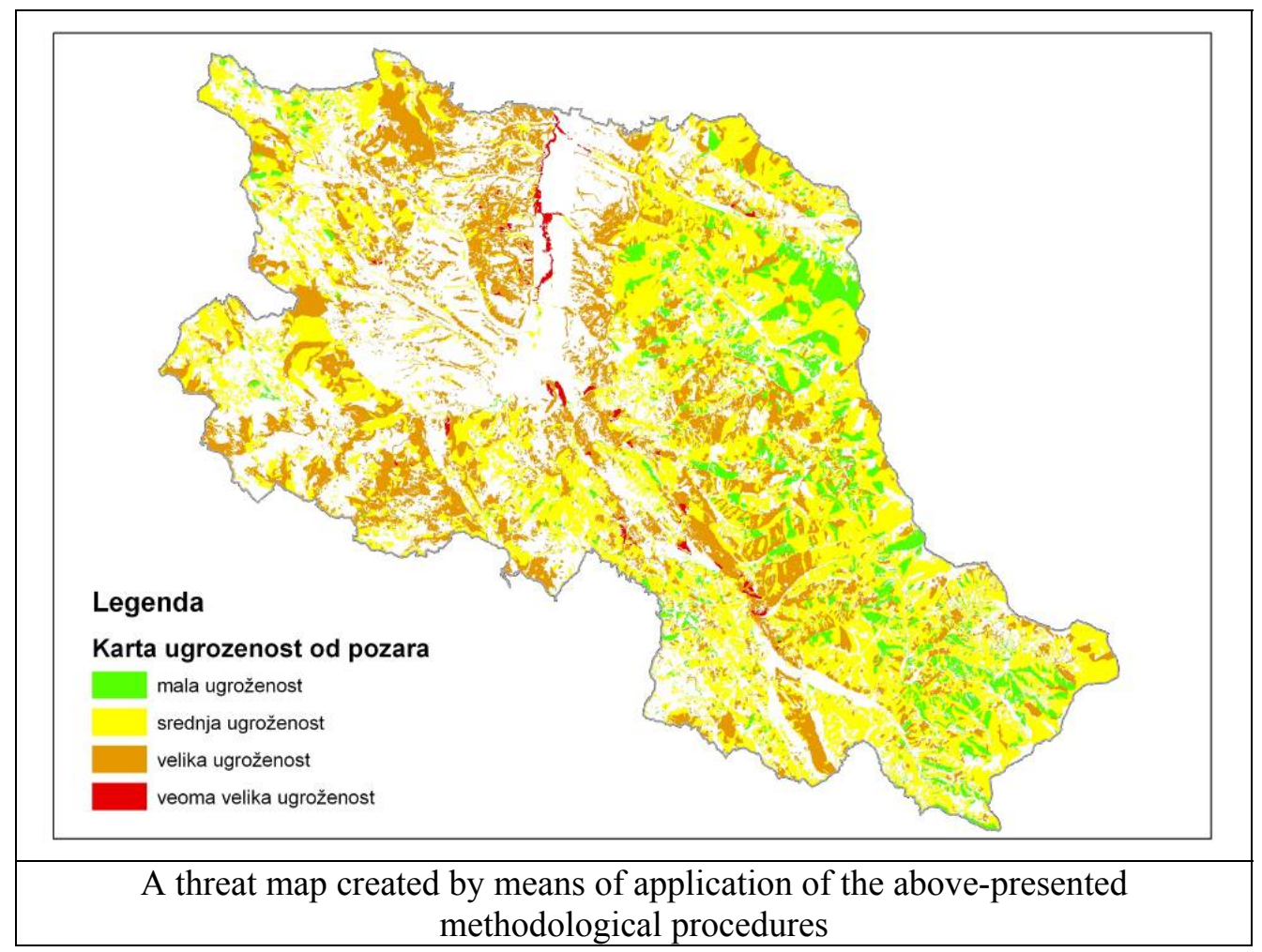

\section{REFERENCES}

Cone, P. (1996): Wildfire, The Larner Group

Golubović-Đurguz, V., Ratknić, M., Bilibajkić, S., Braunović, S., Rajković, S. (2007): Zdravstveno stanje i zaštita od požara kultura podignutih na goletima, Rad u tematskom zborniku „Pošumljavanje goleti i antropogeno oštećenih zemljišta“, Institut za šumarstvo, Beograd, ISBN 978-86-80439-08-2. Izdavač: Institut za šumarstvo, Beograd. pp 183-193

Đorđević, G. (1998): 'Elementi za izradu planova sprečavanja nastanka i gašenja šumskih požara, seminarski rad Fakultet zaštite na radu

Đorđević, G. (2007): Prevencija nastanka i širenja šumskih požara, časopis "Zaštita u praksi"

Đorđević, G. (2004): Metode gašenja šumskih požara, časopis "Zaštita u praksi", Beograd,

Đorđević, G. (2006): Zaštita šuma od požara, zbornik radova "Ekološka istina", Sokobanja. Đorđević, G. (2008): Procena štete nastalih usled šumskih požara i način smanjenja ovih troškova", Zbornik radova, 11.Međunarodna konferencija zaštite od požara i eksplozija, N.Sad.

Đorđević, G. (2008): Zaštita šuma od požara-problemska pitanja, Zbornik radova "Ekološka istina", Sokobanja.

Đorđević, G. (2004): Model izrade planova za sprečavanje nastanka i gašenje šumskih požara, Zbornik radova, 9. Međunarodno savetovanje zaštite od požara i eksplozija, N.Sad. 
Đorđević, G. (2009): Metoda za određivanje stepena ugroženosti šuma od požara, časopis "Zaštita u praksi", Beograd.

Koylowski T.T. and C.E. Ahgren (1974): Fire and Ecosystems, New York, Academik Press Morrison Ellen E. (1996): Guardian of the forest, Forest Fire Prevention Program.

Radović, V. (2000): Modelovanje šumskih požara u cilju predikcije, Magistarski rad, Fakultet zaštite na radu, Niš.

Ratknić, M., Vasiljević, A. (2001)- Ekspertni sistem za zaštitu šuma od požara, Zbornik radova Simpozijum o računarskim naukama i informacionim tehnologijama - YU INFO 2000, 19-23. mart, Kopaonik, YUNIS CD - izdanje

Ratknić, M., Rakonjac Lj., Braunović S., Bilibajkić S. (2006): Fire protection in the National park Kopaonik, Internacional Sciantific Conference In occasion of 60 year of operation of Institute of Forestry, Belgrade, Serbia. SUSTAINABLE USE OF FOREST ECOSYSTEMS The Challenge of the $21^{\text {st }}$ Century, Proceedings pp. 280-284, 8-10 November, 2006., Donji Milanovac, Serbia

Ratknić, M., Rakonjac, Lj., Matović, M., Bilibajkić, S., Braunović, S. (2006): Razvoj ekspertog sistema za zaštitu šuma od požara u Nacionalnom parku Tara, International Scientific Conference Management of Forest Ecosystems in National Parks and Other Protected Areas, Jahorina-Tjentište. Proceedings, pp 381-388.

Ratknić, M., Brusin, S., Bojović, M., Kucera, J., Hatala, N., Valach, L. (2008): Metodologija izrade plana gazdovanja šumama, Razvoj kapaciteta privatnog sektora za održivo gazdovanje šumama u Srbiji - Budovanie kapacit sukromneho sektora pre trvalo udržatelne obhospodarovanie lesov v Serbskej Republike, SlovakAid - Bratislava (Slovakia), National Forest centre- Zvolen (Slovakia), Institut za šumarstvo, pp 127-221 